\title{
CYCLIC CHANGES IN GONADAL MATURATION AND HISTOLOGICAL OBSERVATIONS OF THREATENED FRESHWATER CATFISH "NARIKELIRU” MYSTUS MONTANUS (JERDON, 1849)
}

\author{
Antonysiluvai J. AROCKIARAJ ${ }^{1 *}$, Mohammed A. HANIFFA ${ }^{1}$, \\ Sankaran SEETHARAMAN ${ }^{1}$, Shriprakash SINGH ${ }^{2}$ \\ ${ }^{1}$ Centre for Aquaculture Research and Extension (CARE) St. Xavier's College \\ (Autonomous), Tamil Nadu, India \\ ${ }^{2}$ National Bureau of Fish Genetic Resources, Dilkusha (P.O), Lucknow, \\ Uttar Pradesh, India
}

Arockiaraj A.J., Haniffa M.A., Seetharaman S., Singh S., 2004. Cyclic changes in gonadal maturation and histological observations of threatened freshwater catfish "narikeliru" Mystus montanus (Jerdon, 1849). Acta Ichthyol. Piscat. 34 (2): 253-266.

Background. Usage of biosciences in increasing fish production needs to have a proper understanding and knowledge of endocrine physiology of fish reproduction. The most suitable method of determining the reproductive cycle in fishes is to observe seasonal development changes in the gonads. The present paper describes morphological changes in gonads of Mystus montanus.

Materials and Methods. The individuals of M. montanus were sampled monthly in captive condition throughout one year to determine the changes occurring in gonadal histology and reproductive status. The stages of gonadal maturation and the seasonal changes in the proportion of oocyte development within the ovaries were noticed and maturity stages were assessed by microscopic and also macroscopic observations.

Results. The peak spawning period of Mystus montanus was noticed during November-January in male and October-December in female. The size at first maturity was $10-11 \mathrm{~cm}(8-12 \mathrm{~g})$ in male and $13-14 \mathrm{~cm}(14-16 \mathrm{~g})$ in female, respectively. $M$. montanus spawned only once in a year with the onset of north-east monsoon. The gonadosomatic index (GSI) ranged from 2.8 to 8.5 in males and from 4 to 16 in females and their condition factor (CF) was 4-6 and 6-9, respectively.

Conclusion. The sequence of gonadal maturation in $M$. montanus is morphologically and histologically divided into five stages viz. immature, maturing, mature, matured, and spent or rest.

Key words: gonadal maturation, histology, freshwater catfish, Mystus montanus.

* Correspondence: Dr Antonysiluvai Jesu Arockiaraj, Centre for Aquaculture Research and Extension (CARE) St. Xavier's College (Autonomous), Palayamkottai - 627 002,Tamil Nadu, India, e-mail: jesuaraj@ rediffmail.com 


\section{INTRODUCTION}

The spawning biomass is employed routinely in stock assessments of fishes as indicators of reproductive potential. For proper management of a fishery, a thorough study of maturation cycles and depletion of gonads is important, since such a study is aimed in understanding and predicting the annual changes of the population (Thorpe et al. 1990, Jobling et al. 2002, Tomkiewicz et al. 2003, Shein et al. 2004). The reproductive cycles in teleost occurs during a particular phase; some breed once in a year as annual breeders and others as monsoon breeders (Zuckerman 1962).

Cyclic changes in the gonads (ovaries and testes) have been examined in a few species viz. Channa marulius (Hamilton, 1822)(cf. Parameswaran and Murugesan 1976), C. punctata (Bloch, 1793)(cf. Srivastav and Srivastav 1998), C. striata (Bloch, 1793)(cf. Haniffa et al. 2000), "Clarias lazera" = Clarias gariepinus (Burchell, 1822)(cf. Richter and van den Hurk 1982), C. macrocephalus Günther, 1864 (cf. Mollah 1986), C. batrachus (Linnaeus, 1758)(cf. Fagbenro et al. 1992), "M. nemurus" = Hemibagrus nemurus (Valenciennes, 1840)(cf. Khan et al. 1990), Leiognathus brevirostris (Valenciennes, 1835)(cf. Jayawardane and Dayaratne 1998), Nemipterus randalli Russell, 1986 (cf. Rao 2003) and Micropogonias furnieri (Desmarest, 1823)(cf. Vicentini and Araújo 2003). The purpose of the present study was to observe the changes in gonadal maturation and their histological differentiation of the threatened freshwater catfish Mystus montanus.

\section{MATERIALS AND METHOD}

Fingerlings of $M$. montanus ( 88 males and 114 females) $(5.5 \pm 0.4 \mathrm{~cm} ; 3.8 \pm 0.38 \mathrm{~g})$ were collected from the Tambaraparani River (irrigation canal) by a cast net during February 2000, transported to the Centre for Aquaculture Research and Extension (CARE), and acclimatized in cement tanks $(3 \times 1 \times 1 \mathrm{~m})$ for a week period by feeding finely chopped chicken intestine ad libitum. They were introduced into the culture pond $(8.3 \times 7.6 \times 3 \mathrm{~m})$ supplied with bore-well water (dissolved oxygen $5.8 \mathrm{mg} \cdot \mathrm{l}^{-1}$, temperature $29 \pm 2{ }^{\circ} \mathrm{C}$, and $\mathrm{pH}$ 6.8-7.2) and the experiment was conducted between April 2000 and March 2001. During the experimental period they were fed formulated diets following Haniffa et al. (1999) (60\% chicken intestine, 17\% ground nut oil cake, $11 \%$ rice bran, $10 \%$ tapioca, and $2 \%$ vitamin and mineral mixture). The test individuals were sampled monthly (5-10 individuals) by a drag net. The growth performance values were estimated and the feeding level was adjusted accordingly. The fish were raised up to adult stage.

During monthly sampling the fish were taken out and the gonads were dissected and weighed. The gonadal maturation was assessed by microscopic and also macroscopic observations. Gonadosomatic index (GSI) and condition factor (CF) have been calculated following Billard et al. (1993). 
Histological observations were made in every maturity season and / or stages during sampling. Small pieces of ovary $(6-8 \mathrm{~mm})$ and testicular follicle $(4-6 \mathrm{~mm})$ were fixed in Bouin's solution for $48 \mathrm{~h}$ and subsequently processed for histology following Degani (1994). Each piece of tissue, embedded in paraffin wax was sectioned at $5 \mathrm{~mm}$ and stained either with Ehrlich haematoxylin or Heidenhain's iron haematoxylin and counter stained with eosin.

\section{RESULTS}

At maturity the range of total length of the fish was $10-11 \mathrm{~cm}$ in males and 13-14 $\mathrm{cm}$ in females while the range of body weight was 8-12 $\mathrm{g}$ and $14-16 \mathrm{~g}$, respectively. Cyclic changes studied in relation to different maturity stages and the following maturity stages have been observed seasonally (Table 1).

The male and female fish showed weight changes in the gonads, corresponding to the three gametogenic stages (pre-spawning, spawning, and post spawning). In the prespawning period there was a gradual increase in the gonadosomatic index (GSI) $(2.9 \pm 0.3$ and $3.9 \pm 0.5)$, which showed a marked, increase $(9.7 \pm 1.2$ and $15.8 \pm 2.1)$ reaching a peak during the spawning period and a gradual decrease $(4.5 \pm 0.9$ and 4.3 \pm 0.5 ) in the post-spawning period in males and females respectively. Their respective $\mathrm{CF}$ increased gradually during the pre-spawning period $(6.1 \pm 0.2$ and $6.4 \pm 0.3)$ and decreased thereafter $(5.8 \pm 0.3$ and $4.9 \pm 0.4)$ during the spawning season and again it automatically increased when the gonads entered the atresia stage. So there was a linear relationship between GSI and CF, when GSI increased CF decreased and when CF decreased-GSI increased accordingly (Figs. 1, 2).

Table 1

Stages of maturity at different periods in M. montanus

\begin{tabular}{|c|c|c|c|}
\hline \multirow{2}{*}{$\begin{array}{l}\text { Stage } \\
\text { No. }\end{array}$} & \multirow{2}{*}{ Stage } & \multicolumn{2}{|c|}{ Period } \\
\hline & & Male & Female \\
\hline I & $\begin{array}{l}\text { Pre-spawning } \\
\text { (immature) }\end{array}$ & April-May & March-May \\
\hline II & $\begin{array}{c}\text { Pre-spawning } \\
\text { (maturing or rebuilding) }\end{array}$ & June-August & June-July \\
\hline III & Pre-spawning (mature) & September-October & August-September \\
\hline IV & $\begin{array}{c}\text { Spawning } \\
\text { (fully matured or ripe) }\end{array}$ & November-January & October-December \\
\hline $\mathrm{V}$ & $\begin{array}{l}\text { Post-spawning } \\
\text { (spent or resting) }\end{array}$ & February-March & January-February \\
\hline
\end{tabular}


The gradual changes in the weight of the testes were not uniform and did not coincide with the peaks of the female fish. The weight of the testes gradually increased in the months of June through August reaching a peak in October and remained as such up to January, and then began to decrease till March, after which it again increased till May. Whereas the weight of the ovary increased gradually during the months of June-July reaching a peak in October-December and then decreased till February and after which it again increased till May. The five maturity stages of gonads of the male and female M. montanus determined (Fig. 3a, b) based on the morphology of gonads are presented in the following Table 2 .

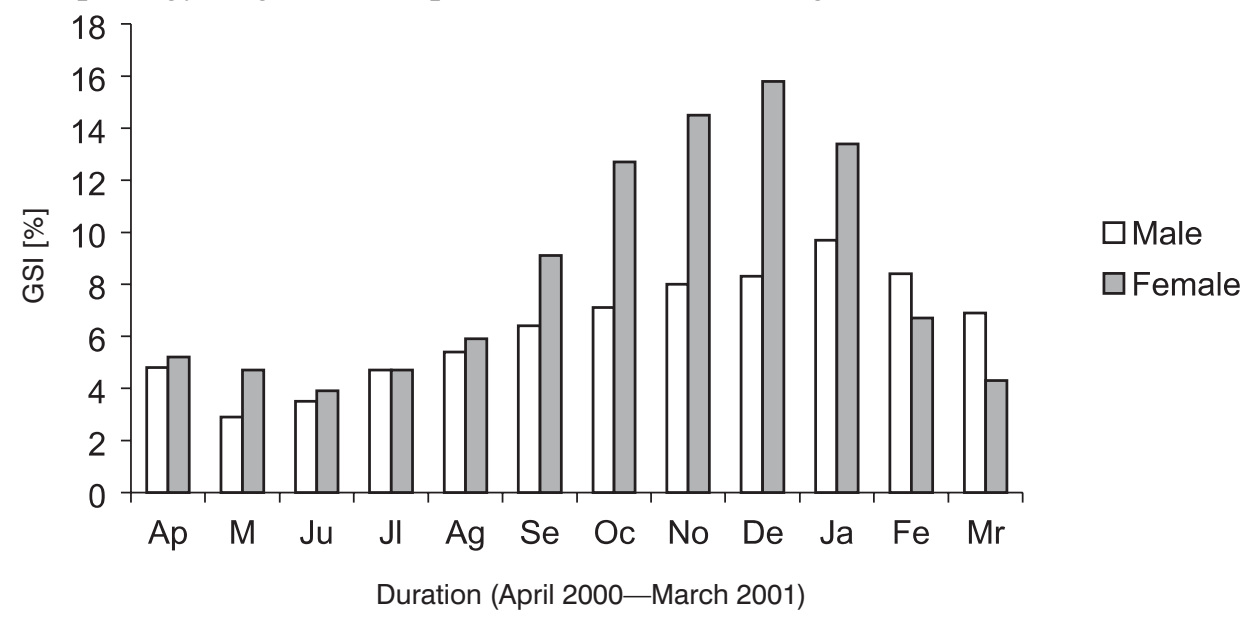

Fig 1. Seasonal changes of average gonadosomatic index (GSI) for males and females of $M$. montanus

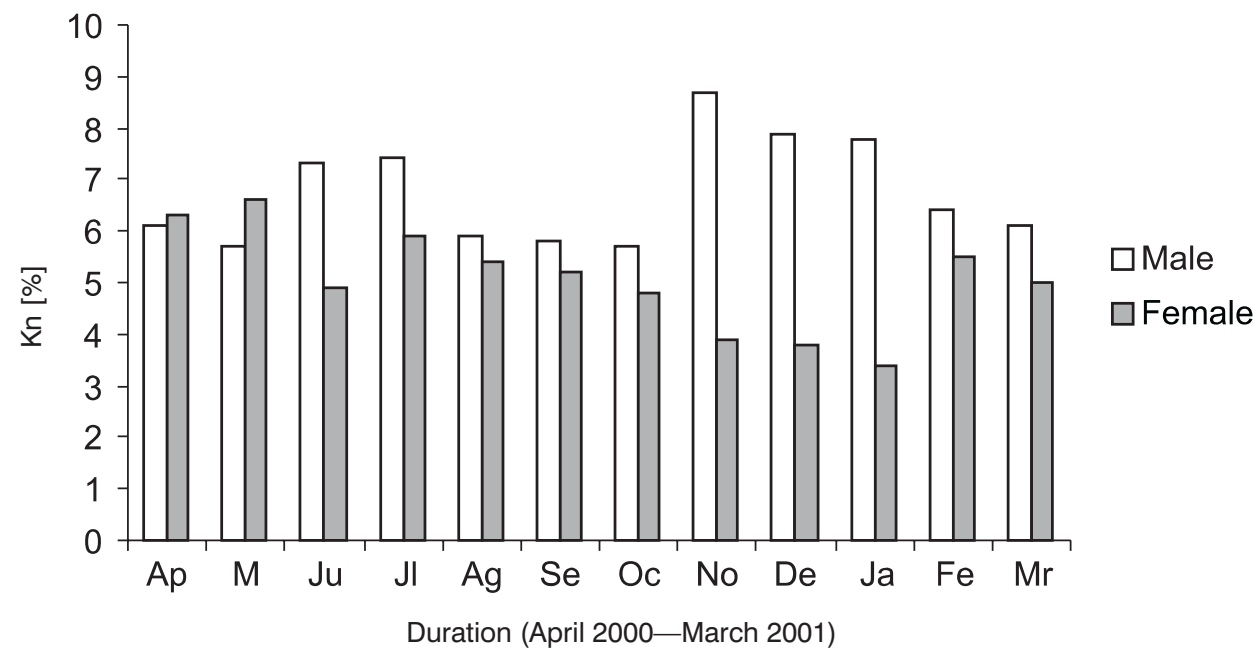

Fig 2. Seasonal changes of average condition factor $(\mathrm{kn})$ for males and females of M. montanus 
Table 2

\section{Gonadal condition of different maturity stages of male and female $M$. montanus}

\begin{tabular}{|c|c|c|c|}
\hline \multirow{2}{*}{$\begin{array}{l}\text { Spawning } \\
\text { period }\end{array}$} & \multirow[t]{2}{*}{ Maturity stage } & \multicolumn{2}{|c|}{ Gonadal condition } \\
\hline & & Male & Female \\
\hline Pre-spawning & $\begin{array}{c}\mathrm{I} \\
\text { (immature) }\end{array}$ & $\begin{array}{l}\text { Testes very fine, colourless, } \\
\text { elongate, thread-like; left slightly } \\
\text { longer than right one }\end{array}$ & $\begin{array}{l}\text { Right and left ovaries more or } \\
\text { less equal in length and size; } \\
\text { colourless to whitish; eggs } \\
\text { very minute, distinct only } \\
\text { under microscope (Fig. 3c) }\end{array}$ \\
\hline Pre-spawning & $\begin{array}{c}\text { II } \\
\text { (maturing } \\
\text { or rebuilding) }\end{array}$ & $\begin{array}{l}\text { Reddish-white or creamy-white; } \\
\text { left slightly longer than right one }\end{array}$ & $\begin{array}{l}\text { Ovary considerably larger; } \\
\text { white or yellowish-white; } \\
\text { maturing eggs visible through } \\
\text { wall under microscope; left } \\
\text { ovary longer than right one } \\
\text { (Fig. 3d) }\end{array}$ \\
\hline Pre-spawning & $\begin{array}{c}\text { III } \\
\text { (mature) }\end{array}$ & $\begin{array}{l}\text { Stages II and III cannot be } \\
\text { distinguished clearly; both stages } \\
\text { more or less similar }\end{array}$ & $\begin{array}{l}\text { Yellowish-white; shorter than } \\
\text { fully mature ovary; differs } \\
\text { from fully mature one in its } \\
\text { colour (quite yellow in case } \\
\text { of fully mature ovary) } \\
\text { (Fig. } 3 \mathrm{~g} \text { ) }\end{array}$ \\
\hline Spawning & $\begin{array}{l}\text { IV } \\
\text { (fully matured } \\
\text { or ripe) }\end{array}$ & $\begin{array}{l}\text { Testes are elongate, bulged, and } \\
\text { dark-reddish to yellowish or } \\
\text { creamy-white plus additional red } \\
\text { spots }\end{array}$ & $\begin{array}{l}\text { Yellowish to yellow-white; } \\
\text { ovaries visible through } \\
\text { translucent body wall of } \\
\text { abdomen from outside; } \\
\text { vagina becoming dark-pink; } \\
\text { one or two ripe eggs } \\
\text { remaining in oviduct (Fig. } 3 \text { f) }\end{array}$ \\
\hline $\begin{array}{l}\text { Post- } \\
\text { spawning }\end{array}$ & $\begin{array}{l}\mathrm{V} \\
\text { (spent or } \\
\text { resting) }\end{array}$ & $\begin{array}{l}\text { White; red spots still visible; left } \\
\text { testis longer than right one; } \\
\text { testes seem to be dorsoventrally } \\
\text { flattened }\end{array}$ & $\begin{array}{l}\text { Slightly shorter than fully } \\
\text { mature one; a number of } \\
\text { immature and a few mature } \\
\text { yellow eggs still remaining in } \\
\text { nearly empty bag; bag } \\
\text { transparent and yellow eggs } \\
\text { visible from outside (Fig. } 3 \mathrm{~g} \text { ) }\end{array}$ \\
\hline
\end{tabular}


Table 3

\section{Histological differentiation of the gonadal condition of male and female M. montanus}

\begin{tabular}{|c|c|c|c|}
\hline \multirow{2}{*}{$\begin{array}{l}\text { Spawning } \\
\text { period }\end{array}$} & \multirow{2}{*}{ Maturity stage } & \multicolumn{2}{|c|}{ Histological differentiation } \\
\hline & & Male & Female \\
\hline Pre-spawning & $\begin{array}{c}\mathrm{I} \\
\text { (immature) }\end{array}$ & $\begin{array}{l}\text { Nuclear diameter } 5.7-2.7 \mu \mathrm{m} \text {; } \\
\text { nucleus of sperm atogonium with } \\
\text { centrally-located nucleolus } \\
\text { (occasionally with two nucleoli) } \\
\text { (Fig. 4a) }\end{array}$ & $\begin{array}{l}\text { Large, intensely stained } \\
\text { nucleus; cytoplasm } \\
\text { containing few primary } \\
\text { oocytes; oocytes surrounded } \\
\text { by follicular epithelium } \\
(20-40 \mu \mathrm{m} \text { in diameter) } \\
\text { (Fig. 5a) }\end{array}$ \\
\hline Pre-spawning & $\begin{array}{c}\text { II } \\
\text { (maturing } \\
\text { or rebuilding) }\end{array}$ & $\begin{array}{l}\text { Spermatogonia to primary } \\
\text { spermatocytes, } 3.9-4.8 \mu \mathrm{m} \text { in } \\
\text { diameter; nuclei } 2.5-2.7 \mu \mathrm{m} \text { in } \\
\text { diameter; nucleus staining purple } \\
\text { in } \mathrm{H}+\mathrm{E} \text { (Fig. } 4 \mathrm{~b} \text { ) }\end{array}$ & $\begin{array}{l}\text { Chromatide threads visible; } \\
\text { oocytes growing rapidly; } \\
\text { follicular epithelium still } \\
\text { visible; ger minal vesicle } \\
\text { more or less oval; nuclei } \\
\text { attached to inner border of } \\
\text { nuclear membrane ( } 42-65 \mu \mathrm{m}) \\
\text { (Fig. } 5 \mathrm{~b} \text { ) }\end{array}$ \\
\hline Pre-spawning & $\begin{array}{c}\text { III } \\
\text { (mature) }\end{array}$ & $\begin{array}{l}\text { Primary- to secondary } \\
\text { spermatocytes; nuclear diameter } \\
2.6-3.5 \mu \mathrm{m} \text {; dense chromatin } \\
\text { usually dispersing along threads } \\
\text { throughout nucleus (Fig. } 4 \mathrm{c} \text { ) }\end{array}$ & $\begin{array}{l}\text { Secondary growth phase of } \\
\text { oocytes; germinal reside } \\
\text { oval and lobulated; nuclei } \\
\text { enlarging during } \\
\text { vacuolization of cytoplasm; } \\
\text { membranes of theca externa } \\
\text { and interna and inner layer } \\
\text { of zona pellucida or radiata } \\
\text { visible }(75-102 \mu \mathrm{m} \text { ) } \\
\text { (Fig. } 5 \mathrm{c} \text { ) }\end{array}$ \\
\hline Spawning & $\begin{array}{l}\text { IV } \\
\text { (fully matured } \\
\text { or ripe) }\end{array}$ & $\begin{array}{l}\text { Nucleus }(0.4-2.1 \mu \mathrm{m} \text { in } \\
\text { diameter) staining deeply with } \mathrm{H} \\
+\mathrm{E} \text {; finely formed spermatids } \\
\text { (Fig. 4d) }\end{array}$ & $\begin{array}{l}\text { Completely mature eggs; } \\
\text { follicular tissue much } \\
\text { reduced; germinal vesicle } \\
\text { still oval; nucleoli reduced } \\
\text { in number (Fig. 4d) }\end{array}$ \\
\hline $\begin{array}{l}\text { Post- } \\
\text { spawning }\end{array}$ & $\begin{array}{l}\mathrm{V} \\
\text { (spent or } \\
\text { resting) }\end{array}$ & $\begin{array}{l}\text { Spermatozoa darkly -stained; } \\
\text { kidney-shaped nuclei (1.1-1.4 } \\
\mu \mathrm{m} \text { in diameter); 1obules mainly } \\
\text { packed with mature } \\
\text { spermatozoa, each having a } \\
\text { distinct tail (Fig. 4e) }\end{array}$ & $\begin{array}{l}\text { Fully mature eggs; showing } \\
\text { few advanced oocytes and } \\
\text { undergoing atresia; ovary } \\
\text { appearing very slender with } \\
\text { prominent ovocoel } \\
\text { (Fig. 5e) }\end{array}$ \\
\hline
\end{tabular}




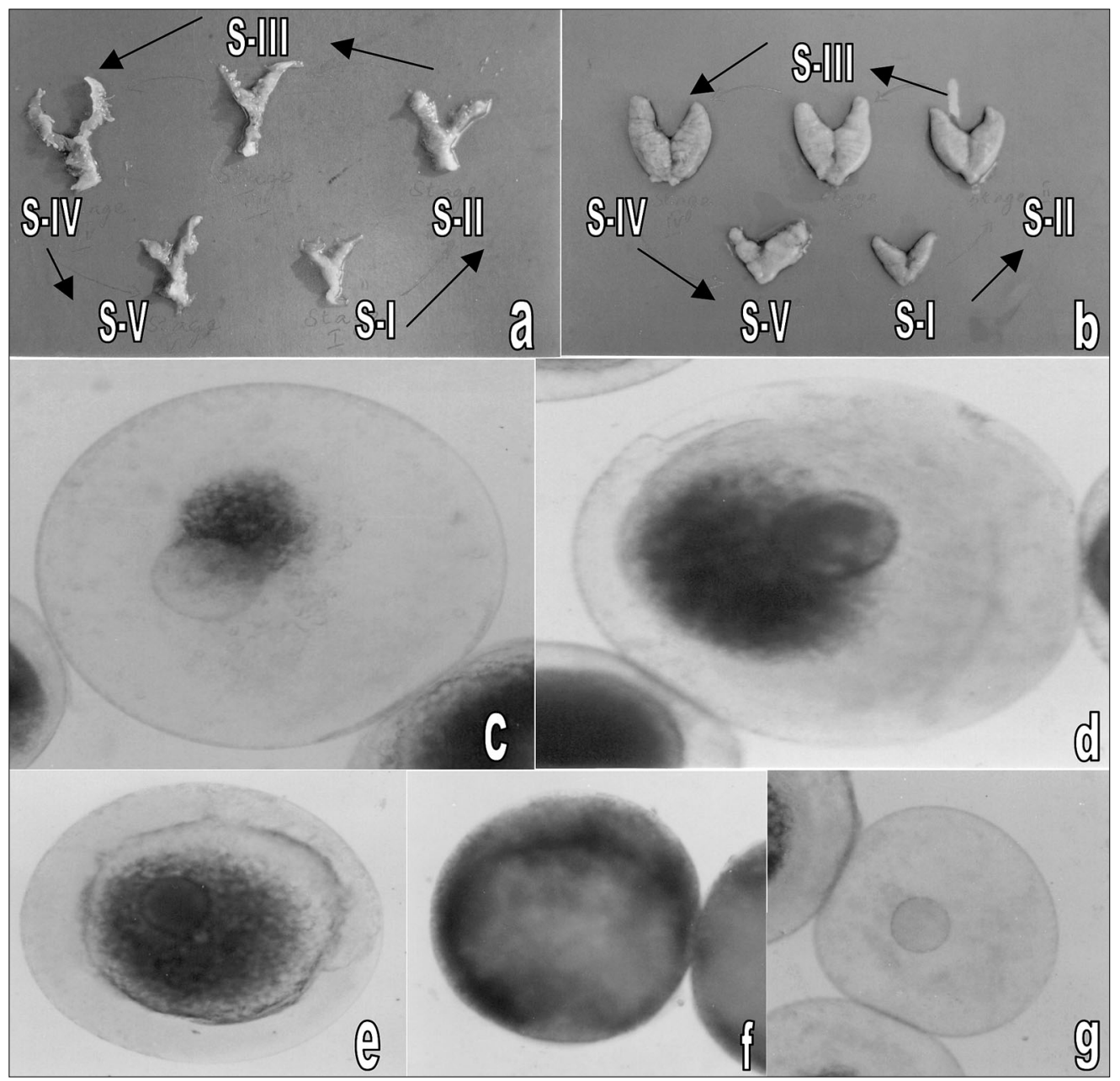

Fig. 3a-g. Mystus montanus; aspects of reproduction. Fig 3a. Five sequential maturity stages (S-I-S-V) of testis. Fig. 3b. Five sequential maturity stages (S-I-S-V) of ovary. Fig. 3c-g. Observation of nuclear position in egg during five different maturity stages of ovary (4x). Fig. 3c. Immature ovum (S-I). Fig. 3d. maturing or rebuilding ovum (S-II). Fig. 3e. Mature ovum (S-III) (early). Fig. 3f. Fully-mature or ripe ovum (S-IV). Fig. 3g. Spent or resting ovum $(\mathrm{S}-\mathrm{V})$ 


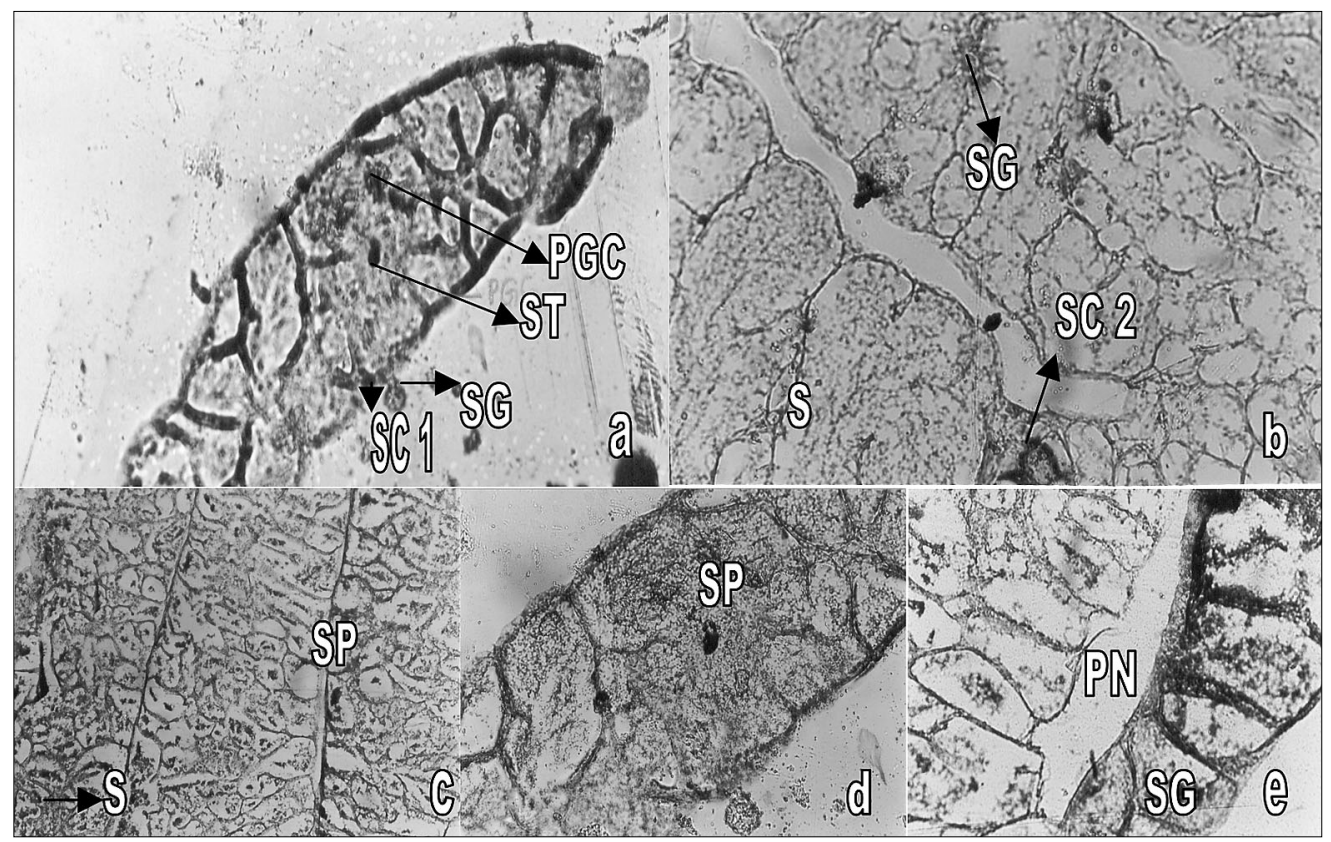

Fig. 4a-e. Histological appearance of testis maturation in M. montanus. Fig. 4a. immature testis (S-I) (4×). Fig. 4b. Mature or rebuilding testis (S-II) $(10 \times)$. Fig. 4c. Mature testis (S-III) (early) (10x). Fig. 4d. Fully-mature or ripe testis (S-IV) (10x). Fig. 4e. Spent or resting testis (S-V) (10x); PGC, primary germ cells; SG, spermatogonia; SC 1, primary spermatocyte; SC 2, secondary spermatocyte; ST, spermatid; SP, spermatozoa; PN, pycnotic nets of degenerating cells 


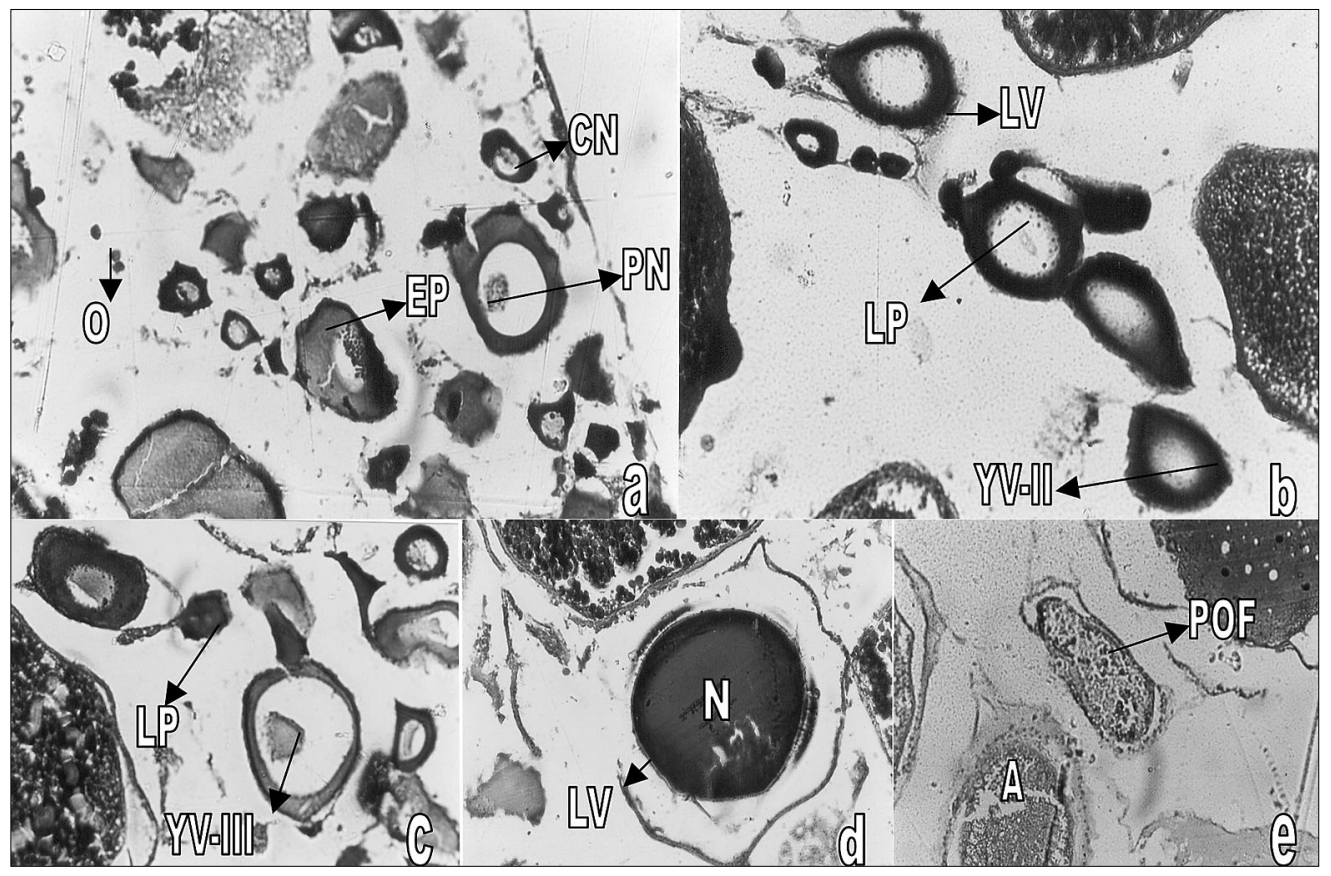

Fig. 5a-e. Histological appearance of ovary maturation in M. montanus. Fig. 5a. Immature ovary (S-I) (4×). Fig. 5b. Mature- or rebuilding ovary (S-II) $(10 \times)$. Fig. 5c. Mature ovary (S-III) (early) (10x). Fig. 5d. Fully-mature or ripe ovary (S-IV) (10x). Fig. 5e. Spent or resting ovary (S-V) (10x); O, oogonia; $\mathrm{CN}$, chromatin nucleus; $\mathrm{PN}$, peri-nucleus; $\mathrm{EP}$, early perinucleus; LV, lipid vesicle; LP, late peri-nucleus; YV-II, yolk vesicle II; YV-III, yolk vesicle III; POF, post ovulatory follicle; A, atresia 


\section{Histological observations of gonad}

Primary germ cells occurred in the intertitial tissue as well as in the wall of the resting lobules. They occurred in small number throughout the year, but were most prominent after the breeding season when they divided mitotically to form nests of oogonia. Each of these large and relative inconspicuous cells showed light staining often with peripheral chromatin and each with a single nucleolus (Table 3).

Each testis was enclosed by a thick tunica albuginea. The testis was attached to the dorsal body wall by the connective tissue mesorchium. Each testis was composed of numerous thin walled lobules. Within the lobules, cells in various stages of spermatogenesis were present in discrete nests of cells, each nest consisting of cells at the same stage of development. During the breeding seasons the lobules became greatly distended with spermatids and spermatozoa (Table 2).

\section{DISCUSSION}

The highest values of CF and GSI were due to the active somatic energy accumulation and the lowest CF and GSI due to the somatic energy depletion (Encina and Lorencio 1997). The variation probably due to the fact that the changes in energy are usually more than the seasonal weight variations as was found by Scott et al. 1980

Photoperiod was also affect the CF and GSI as reported by Hansen et al. (2001) in Gadus morhua Linnaeus, 1758. Cambray and Bruton (1984) pointed out that the similarity in the CF and GSI, annual cycle and the fact that the seasonal pattern common among juveniles and adult fish, suggest that the seasonal variations encountered were more related to variations in food availability than to the reproductive cycle. However some divergence registered in the seasonal pattern among juvenile and adult fish suggest that gonadal development and spawning action could also affect the somatic energy storage in adult fish. CF and GSI values were relative more stable over the year for the juveniles than for the adult fish. On the other hand CF and GSI values showed a parallel pattern throughout all the annual cycle in juveniles.

Gonadal development and reproductive strategy have been described in many teleost fish species in an effort to understand the time course and energetic consequences of reproductive effort. Oocyte growth follows a similar general pattern in most teleosts (Maddock and Burton 1999, Knuckey and Sivakumaran 2001). In the present investigation, five different maturity stages of gonads have been described. Similar observations were made in "Gobioides rubicundus" = Odontamblyopus rubicundus (Hamilton, 1822) by Kader et al. (1988). In O. rubicundus the spawning season differed from $M$. montanus. $O$. rubicundus mainly breeds in late January to early February and late June to early October. In the present investigation, M. montanus breeds from October to December.

Those fish that undergo gonadal maturation during periods of lower food availability such as Hippoglossoides platessoides (Fabricius, 1780) and Pleuronectes platessa Linnaeus, 1758 are thought to utilize somatic energy reserves, particularly 
protein for reproductive growth (Roff 1982, Sivakumaran et al. 2003). Vitellogenesis is one of the most important reproductive phenomenons in egg-laying animals. Vitellogenin is synthesized in the liver under hormonal influence and is deposited in growing oocytes as yolk protein, which serves as building and energy material after fertilization during embryogenesis till hatchlings start feeding.

Histology revealed the reabsorption of both tertiary yolk stage oocytes and the other second growth phase oocytes. This resolves some conflicting reports found in earlier studies (Palmer et al. 1995). Daiber (1953) reported three distinct size classes of oocytes and concluded that the largest were released during spawning, the middle size were released the next year, and the smallest were released in subsequent year.

The post ovulatory follicles degenerate rapidly, making it difficult to assess the percentage of oocytes spawned unless samples are collected daily (Hunter and Macewicz (1985). Also the elastic nature of ovarian tissue allows the ovary to contract as oocytes are spawned so that the remaining oocytes are still closely grouped, making oocytes loss less apparent. It is also difficult to determine whether the observed atresia represented premature reabsorption of oocytes that could have been released later or it was part of the natural tissue resorption process after cessation of spawning. However, the fact that atresia was observed while GSI was still high and that atretic oocytes were found in ovaries that also displayed germinal vesicle maturation suggest that atresia may decrease the reproductive potential of $M$. montanus.

The testes maintained more weight from October to January and these four months may be considered to be the peak spawning season of the male M. montanus. The attainment of early maturation and maintenance of more weight for a longer period by the testes probably facilitate and ensure successful fertilization. Htun-Han (1978) and Nash (1982) also observed earlier maturation and maintenance of more weight by the testes for longer periods than the ovaries in Limanda limanda (Linnaeus, 1758) and Lesueurigobius friesii (Malm, 1874), respectively. The existence of spawning season in M. montanus has been established through the present histological study. Similar observations were made in C. macrocephalus by Mollah and Tan (1982) and Mollah (1986).

Davis (1977) also reported the presence of dense connective tissue and occasional blood vessels in the tunica albuginea covering the testis of an Australian catfish Tandanus tandanus (Mitchell, 1838) similar to those observed in M. montanus. The interlobular space is occupied by blood vessels, nerve fibres (Gresik et al. 1973), fibroblast cells, collagen fibres and other cell types, which vary in different species. In M. montanus, the interlobular space is occupied by blood vessels and smooth muscles. It is possible that the same species may not possess all the cell types presented in other fish species. It was Okuzawa et al (1989) who suggested that elastic tissue might be responsible for contraction of the testis and discharge of sperm although he was unable to demonstrate the presence of elastic fibres. In "Eucalia inconstans" = Culaea inconstans (Kirtland, 1841), however, elastic fibres were found in the walls of the testis and were especially visible after spawning (Ruby and McMillan 1970). 
The cyst wall consists one or more cells which appear to play a role similar to that of Sertoli cells of tetrapod and indeed they have been called Sertoli cells by some scientists (King et al. 1995). The Sertoli cells surround cysts of germ cells in $M$. montanus and therefore, were mostly seen in the immature testes. The seminiferous tubules (ampullae) are composed of many spore sacs. These spore sacs are separated by a thin layer of follicular cells (Sertoli cells) in each spore sac there is plenty of synchronously developing germ cells (spermatocytes and spermatids). After formation of sperms, spore sacs disintegrate and sperm enter the cavity of seminiferous tubules secreted by testis forming the so-called milt (Srivastav and Srivastav 1998).

Development of sperm passes through 3 stages i.e. multiplication stage, growth stage, and maturation stage (Shein et al. 2004). Just as the ovary, the testicular maturity can be judged by visual observations by morphological and histological observations (Rath 2000). However the stages can be classified as stage I (resting phase), stage II (late immature phase), stage III (maturity phase), stage IV (mature phase), and stage $\mathrm{V}$ (spent phase).

\section{ACKNOWLEDGEMENTS}

The financial support of this study by the Indian Council of Agricultural Research-National Agricultural Technology Project (ICAR-NATP) is gratefully acknowledged. Special thanks are due to Dr. A.G. Ponniah, the former Director and Dr. D. Kapoor, Director, National Bureau of Fish Genetic Resources (NBFGR), Lucknow who selected our Centre for Aquaculture Research and Extension (CARE), St. Xavier's College for captive breeding research. Thanks are due to Rev. Dr. A. Antonysamy, S.J., Principal, St. Xavier's College, Palayamkottai for providing necessary facilities to carry out this study.

\section{REFERENCES}

Billard R., Cosson J., Crim L.W., 1993. Motility of fresh and aged halibut sperm. Aquatic Living Resources 6: 67-75.

Cambray J.A., Bruton M.N., 1984. The reproductive strategy of a barb Barbus anoplus (Pisces: Cyprinidae) colonizing a man made lake in South Africa. Journal of Zoology, London 204: 143-168.

Daiber F.C., 1953: Notes on the spawning population of the freshwater drum (Aplodinotus grunniens Rafinesque) in Western Lake Erie. American Midland Naturalist 50: 159-171.

Davis T.L.O., 1977. Reproductive biology of the freshwater catfish, Tandanus tandanus Mitchell, in the Gwydir River, Australia I. Structure of the gonads. Australian Journal of Marine and Freshwater Research 28: 139-158.

Degani G., 1994. Effect of gonadotropin and steroids on vitellogenesis during ovarian development in Trichogaster trichopterus. Journal of Aquaculture in the Tropics 9: 15-23.

Encina L., Granado-Lorencio C., 1997. Seasonal changes in condition, nutrition, gonad maturation and energy content in barbel Barbus sclateri inhabiting a fluctuating river. Environmental Biology of Fishes 50: 75-84. 
Fagbenro O.A., Salami A.A., Sydenham D.H.J., 1992. Induced ovulation and spawning in the catfish Clarias isheriensis, using pituitary extracts from non-piscine sources. Journal of Applied Aquaculture 1: 15-20.

Gresik E.W., Quirk G., Hamilton J.B., 1973. Fine structure of the Sertoli cell of the testis of the teleost Oryzias latipes. General and Comparative Endocrinology 21: 210-213.

Haniffa M.A., Arockiaraj A.J., Sridhar S., 1999. Weaning diet for the stripped murrel Channa striatus. Fishery Technology 36 (2): 116-119.

Haniffa M.A., Merlin T., Shaik Mohamed J., 2000. Induced spawning of the striped murrel Channa striatus using pituitary extract, human chorionic gonadotropin, luteinizing hormone releasing hormone analogue, and ovaprim ${ }^{\circledR}$. Acta Ichthyologica et Piscatoria 30 (1): 53-60.

Hansen T., Karlsen O., Taranger G.L., Hemre G., Holm J.C., Kjesbu O.S., 2001. Growth, gonadal development and spawning time of Atlantic cod (Gadus morhua) reared under different photoperiods. Aquaculture 203: 51-67.

Hunter, J.R., Macewicz B.J., 1985. Measurement of spawning frequency in multiple spawning fishes. pp. 79-94. In: Lasker R., (ed.) An egg production method for estimating spawning biomass of pelagic fish: application to the northern anchovy (Engraulis mordax). NOAA Technical Report NMFS 36.

Htun-Han M., 1978. The reproductive biology of the dab Limanda limanda (L.) in the North Sea: seasonal changes in the ovary. Journal of Fish Biology 13: 351-359.

Jayawardane P.A.A.T., Dayaratne P., 1998. Reproductive biology of shortnose ponyfish Leiognathus brevirostris (Valenciennes) from Portugal Bay in the Puttalam Estuary, Sri Lanka. Asian Fisheries Science 10: 189-200.

Jobling S., Beresford N., Nolan M., Rodgers-Gray T., Brighty G.C., Sumpter J.P., Tyler C.R., 2002. Altered sexual maturation and gamete production in wild roach (Rutilus rutilus) living in rivers that receive treated sewage effluents. Biology of Reproduction 66: 272-281.

Kader M.A., Bhuiyan A.L., Manzur-I-Khuda A.R.M.M., 1988. The reproductive biology of Gobioides rubicundus (Ham. Buch.) in the Karnaphuli estuary, Chittagong. Indian Journal of Fisheries 35 (4): 239-250.

Khan M.S., Ambak M.A., Ang K.J., Mohsin A.K., 1990. Reproductive biology of a tropical catfish, Mystus nemurus Cuvier and Valenciennes in Chenderoh Reservoir, Malaysia. Aquaculture and Fisheries Management 21 (2): 173-180.

King W., Berlinsky D.L., Sullivan C.V., 1995. Involvement of gonadal steroids in final oocyte maturation of white perch (Morone americana) and white bass (M. chrysops): In vivo and in vitro studies. Fish Physiology and Biochemistry 14 (6): 489-500.

Knuckey I.A., Sivakumaran K.P., 2001. Reproductive characteristics and per-recruit analyses of blue warehou (Seriolella brama): implication for the south east fishery of Australia. Marine Freshwater. Research 52: 545-587.

Maddock D.M., Burton M.P.M., 1999. Gross and histological observations of ovarian development and related condition changes in American plaice. Journal of Fish Biology, 53: 928-944.

Mollah M.F.A., Tan E.S.P., 1983. HCG-Induced spawning of the catfish Clarias macrocephalus (Gunther). Aquaculture 35: 239-247.

Mollah M.F.A., 1986. Cyclic changes in the ovary of freshwater catfish Clarias macrocephalus (Gunther). Indian Journal of Fisheries 33 (1): 54-65. 
Nash R.D.M., 1982. The biology of fry of Fries' goby Lesueurigobius friesii (Malm), in the Firth of Clyde, Scotland and a comparison with other stocks. Journal of Fish Biology 21: 69-85.

Okuzawa K., Furukawa K., Aida K., Hanyu I., 1989. Effects of photoperiod and temperature on gonadal maturation and plasma steroid and gonadotropin levels in a cyprinid fish honmoroko Gnathopogen cacrulesuns. General and Comparative Endocrinology 75: 139-147.

Palmer E.E., Sorensen P.W., Adelman I.R., 1995. A histological study of seasonal ovarian development in freshwater drum in the Red lakes. Minnesota. Journal of Fish Biology, 47: 199-210.

Parameswaran S., Murugesan V.K., 1976. Observations on the hypophysation of murrels (Ophiocephalidae). Hydrobiologia 50 (1): 81-87.

Rath R.K., 2000. Freshwater Aquaculture. Revised Edition. Scientific Publishers, Jodhpur, India.

Rao, P.Y., 2003. Food and feeding habits of Nemipterus randalli Russell, 1986 of Visakhapatnam, Andhra Pradesh, India. Journal of Aquatic Biology 18 (1): 55-57.

Richter C.J.J., van den Hurk R. 1982. Effects of II-desoxycorticosterone acetate and carp pituitary suspension on follicle maturation in the ovaries of the African catfish, Clarias lazera (C. \& V.).. Aquaculture 29: 53-66.

Roff D.A., 1982. Reproductive strategies in flatfish a first synthesis. Canadian Journal of Fisheries and Aquatic Sciences 39: 1686-1698.

Ruby S.M., McMillan D.B., 1970. Cyclic changes in the testis of the brook stickleback Eucalia inconstans (Kirtland). Journal of Morphology 131: 447-466.

Scott A.P., Bye V.J., Baynes S.M., 1980. Seasonal variation in sex steroids of female rainbow trout (Salmo gairdneri Richardson). Journal of Fish Biology 17: 587-592.

Shein N.L., Chuda H., Arakawa T., Mizuno K., Soyano K., 2004. Ovarian development and final oocyte maturation in cultured sevenband grouper Epinephelus septemfasciatus. Fisheries Science 70 (3): 360-365.

Sivakumaran K.P., Brown P., Stoessel D., Giles A., 2003. Maturation and reproductive biology of female wild carp, Cyprinus carpio in Victoria, Australia. Environmental Biology of Fishes 68: 321-332.

Srivastav S.K., Srivastav, A.K., 1998. Annual changes in serum calcium and inorganic phosphate levels and correlation with gonadal status of a freshwater murrel, Channa punctatus (Bloch). Brazilian Journal of Medical and Biological Research 31 (8): 1069-1073.

Thorpe J.E., Talbot C., Miles M S., Keay D.S., 1990. Control of maturation in cultured Atlantic salmon, Salmo salar in pumped seawater tanks, by restricting food intake. Aquaculture 86: 315-326.

Tomkiewicz J., Tybjerg L., Jespersen Å., 2003. Micro-and macroscopic characteristics to stage gonadal maturation of female Baltic cod. Journal of Fish Biology 62 (2): 253-275.

Vicentini R.N., Araújo F.G., 2003. Sex ratio and size structure of Micropogonias furnieri (Desmarest, 1823) (Perciformes, Sciaenidae) in Sepetiba Bay, Rio de Janeiro, Brazil. Brazilian Journal of Biology 63 (4): 559-566.

Zuckerman S., 1962. The Ovary. Vol. I. Oxford Publication, New York and London. 